\title{
PENERAPAN METODE KONSELING KELOMPOK DALAM UPAYA MENINGKATKAN RASA PERCAYA DIRI SISWA KELAS XII IPA SMAN 2 SUNGAI RAYA
}

\author{
Wira Miharja \\ SMA Negeri 2 Sungai Raya \\ Kec. Sungai Raya, Kab. Kuburaya, Prov. Kalimantan Barat 78391 \\ Alamat e-mail: Wiramiharja2017@gmail.com
}

\begin{abstract}
Abstrak
Penelitian ini bertujuan untuk mengembangkan model bimbingan konseling dalam bimbingan karir pada siswa kelas XII IPA SMA Negeri 2 Sungai Raya. Penelitian ini didasarkan pada kenyataan bahwa kemampuan pemahaman siswa terhadap layanan bimbingan karir masih rendah. Padahal dengan dikuasainya materi ini pada umum siswa tidak mengalami kesulitan untuk mempelajari mata pelajaran lainya. Penelitian ini dilaksanakan pada bulan Januari dan April 2017. Berdasarkan hasil proses penelitian, disampulkan bahwa siswa kelas XII IPA SMA Negeri 2 Sungai Raya sangat antusisas dan termotivasi dalam mengikuti layanan bimbingan, dan prestasi mereka juga meningkat.
\end{abstract}

Kata kunci: Konseling kelompok, Percaya diri

\begin{abstract}
This research aims to develop a counseling model in career guidance for students of class XII IPA in SMA Negeri 2 Sungai Raya. This research is based on the fact that students' ability to understand career guidance services is still low. Even with the mastery of this material in general students do not have difficulty learning other subjects. This research was conducted in January and April 2017. Based on the results of the research process, it was proposed that students of class XII IPA SMA Negeri 2 Sungai Raya were very enthusiastic and motivated to take part in guidance services, and their achievements also increased.
\end{abstract}

Keywords: Group Counseling, Self Confidence

\section{PENDAHULUAN}

Kepercayaan diri siswa merupakan hal yang sulit untuk ditingakatkan. Banyak siswa yang canggung dan tajut salah saat ingin menjawab dan bertanya. Tentu, Anda sering mendapatkan situasi dimana Anda menawarkan pertanyaan atau mengiginkan jawaban, namun siswa hanya diam. Tidak ada satupun dari mereka yang mau bicara. Saya rasa hal itu juga dipengaruhi oleh kepercayaan diri mereka yang rendah.

Dalam kelangsungan perkembangan dan pertumbuhan anak didik, berbagi pelayanan di selenggarakan. Masing-masing pelayana itu memiliki peran yang sangat berguna dalam proses perkembangan anak didik, khususnya dalam bidang tertentu yang menjadi fokus pelayanan. Sebgai contoh peran guru dalam 
pelayanan pendidikan adalah mengajar, mendidik dan membimbing para siswa untuk memperoleh ilmu yang bermanfat dan dapat menggapai cita-cita yang di ingikan.

Seperti halnya pada pelayanan layanan bimbingan karir, konselor dalam hal ini guru BK berperan dalam upaya pemberian bantuan terhadap siswa agar bisa berkembang secara mandiri dan dapat menyelesaikan permasalahannya, yang sedang dihadapi. Salah satu yang masalah yang sedang dihadapi sekolah saat ini adalah lemahnya motivasi belajar siswa.

Di sisi lain ditemukan layanan-layanan bimbingan karir yang tidak menunjukan suatu aktifitas yang membuat siswa untuk belajar secara sungguhsungguh, melainkan aktifitas yang membuat siswa jenuh atau bosan karena model belajar yang monoton. Hal ini, disebabkan karena kurang adanya kreaktifitas seorang guru dalam mengolah proses layanan-layanan bimbingan karir di kelas. Sehingga membuat siswa cendrung kurang termotivasi dalam menerima materi yang diajarkan.

Maka dibutuhkan upaya yang dapat membangkitkan semangat motivasi siswa dalam mengikuti proses layanan-layanan bimbingan karir dengan baik. Salah satu altenatif metode pengajaran yang dapat ditawarkan adalah metode layanan bimbingan karir kelompok. Dimana bentuk bimbingan siswa banyak melakukan kegiatan proses layanan-layanan bimbingan karir, siswa dapat memperoleh keuntungan. Keuntungan atau jasa yang diperoleh dari adanya suatu pelayanan merupakan hasil dari terlaksananya fungsi pelayanan tersebut. Dengan demikian peran kegiatan layanan bimbingan karir dapat diketahuai dengan melihat fungsi-fungsi pelayanan layanan bimbingan karir seperti; fungsi pemahaman, fungsi pencegahan, fungsi pemeliharaan dan pengembangan.

Peran layanan bimbingan karir di sekolah dianggap sebagai polisi sekolah layanan bimbingan karir yang sebenarnya paling memiliki peran dalam pemeliharaan pribadi siswa, ditempatkan dalam konteks tindakan-tindakan yang menyangkut disiplin siswa. Memanggill, memarahi, menghukum adalah proses yang dianggap menjadi label kegiatan layanan bimbingan karir di banyak sekolah. 
Dengan kata lain layanan bimbingan karir di posisikan sebagai musuh bagi siswa yang bermasalah.

Menurut pengalaman dan Tahapan penulis sejak menglayanan bimbingan karir siswa di SMAN 2 Sungai Raya kelas XII IPA Tahun pelajaran 2017/2018, menunjukan hal-hal sebagai berikut; (1) sedikit sekali siswa yang melakukan kegiatan belajar di rumah (2) sedikit sekali animo siswa untuk belajar di perpustakaan. (3) jika ditanyakan hobi, rata-rata hobi olah raga karena olah raga tidak terkait dengan membaca (4) kegiatan yang paling disenangi adalah kegiattan di luar membaca (5) kegiatan hari-hari libur, dihabiskan untuk hal-hal di luar kegiatan belajar (membaca) (6) teknologi komunikasi seperti internet, HP dihabiskan pada hal-hal yang tidak mermanfaat. (7) jika ada PR, tidak dikerjakan di rumah tetapi dikerjakan di sekolah bahkan menyontek haasil pekerjaan kawannya. Kasus tersebut di atas harus segera di selesaikan, maka diri itu penulis melakukan proses kegiatan bimbingan dan layanan bimbingan karir pada siswa yang minat belajarnya rendah.

Berdasarkan permasalahan di atas dicari altenatif solusinya yaitu dengan menerapkan metode layanan bimbingan karir kelompok. Sistem metode layanan bimbingan karir kelompok merupakan salah satu pemberian bantuan secara kelompok (group) dan secara langsung.

\section{METODE}

Untuk menjawab permasalahan yang terjadi di kelas, penulis melakukan Observasi dalam dua tahapan. Observasi tindakan kelas dilakukan pada Tahapan 1 hingga Tahapan 2 dari pertengahan bulan Januari hingga akhir bulan April 2017, dibantu oleh seorang guru rekan sejawat yang bertindak sebagai penulis dan bersifat sebagai teman diskusi dalam tahap refleksi. Adapun yang dilakukan Observasi dapat penulis uraikan dalam tahapan Tahapan-tahapan bimbingan yang dilakukan dalam empat kali pertemuan setiap Tahapan sebagai berikut :

\section{Tahapan 1}

a. Perencanaan 
1) Tim penulis melakukan analisis kurikulum untuk mengetahui kompentensi dasar yang akan disampaikan kepada siswa dalam bimbingan.

2) Membuat rencana bimbingan dengan mengacu pada tindakan yang diterapkan dalam observasi.

3) Menentukan kompetensi dasar bimbingan yang akan diterapkan pada siswa.

4) Membuat lembar kerja siswa (LKS), menyiapkan lembar Tahapan, lembar evaluasi dan daftar nama serta absentasi siswa.

5) Menyiapak sumber belajar seperti buku-buku teks dan kertas karton untuk media model layanan bimbingan karir kelompok.

b. Pelaksanakan

penulis menerapkan tindakan mengacu pada skenario model bimbingan model layanan bimbingan karir kelompok dan LKS. Prosedur bimbingan adalah sebagai berikut:

1) Memiliki tema yang cukup menarik untuk disampikan.

2) Memperkenalkan proses bimbingan pada peserta didik.

3) Menjelaskan poin-poin kunci atau masalah-masalah pokok yang diangkat.

4) Meminta peserta didik untuk mendengarkan guru mengenai kegiatan layanan bimbingan karir.

Pada awal pelaksanaan tindakan Tahapan 1 belum sesuai dengan rencana masih terdapat beberapa kekurangan dala pelaksanankan kegiatan layanan bimbingan karirterutama dalam penggunaan strategi metode layanan bimbingan karir kelompok sehingga interaksi antara guru-siswa-siswa agak terganggu meskipun telah melaksanakan dengan optimal. Pelaksanaan Tindakan 1 suasana kelas kurang tertib. Hal tersebut disebabkan :

1) Adanya suasana kelas yang agak dari biasnya karena kehadiran penulis di kelas.

2) Karena metode layanan bimbingan karir kelompok merupakan hal yang baru bagi menyelesaikan soal.

3) Sebagai siswa belum terbiasa dengan kondisi belajar dengan metode layanan bimbingan karir kelompok. 
4) Sebagai siswa belum memahmi metode layanan bimbingan karir kelompok secara utuh dan menyeluruh.

Untuk mengetahui tersebut dilakukan upaya sebagai berikut :

1) Guru dengan intensif memberikan pengertian kepada siswa tentang metode layanan bimbingan karir kelompok dan keikut serta setiap siswa.

2) Guru membantu memahami langkah-langkah metde layanan bimbingan karir kelompok.

c. Pengamatan (Observasi)

Tahapan yang dilakukan terhadap; (a) Minat siswa, (b) Aktifitas guru, dan (c) kemampuan siswa dalam memahami materi layanan bimbingan karir. Berdasarkan hasil Observasi yang telah dilakukan sebelum Tahapan 1 kegiatan pelaksanakan tindakan kelas diperoleh data bahwa minat dalam memahami proses bimbingan mengalami kenaikan, sebelum Observasi prosentase minat siswa adalah 36,36\%. Hasil Observasi minat peserta didik dalam proses layanan bimbingan karir dapat dilihat pada tabel 3 sebagai berikut:

Tabel 1. Peroleh Skor Kepercayaan diri Siswa dalam Tahapan 1

\begin{tabular}{|c|l|c|c|c|c|c|}
\hline \multirow{2}{*}{ No } & \multirow{2}{*}{ Nama perserta didik } & \multirow{2}{*}{ Produk } & \multicolumn{2}{|c|}{ Performasi } & Jumlah & \multirow{2}{*}{ Naktik } \\
\cline { 4 - 5 } & & Sikap & Skor & Nilai \\
\hline 1 & A. Gunawan & 2 & 2 & 3 & 7,3 & 73 \\
\hline 2 & Ade Maulana Lubis & 2 & 3 & 2 & 5,9 & 59 \\
\hline 3 & Anisa Fernanda & 2 & 3 & 3 & 7,3 & 73 \\
\hline 4 & Aldi Sanjaya & 2 & 3 & 3 & 5,5 & 55 \\
\hline 5 & Anisa Fitri & 1 & 1 & 2 & 6,5 & 65 \\
\hline 6 & Badai & 2 & 2 & 3 & 5,6 & 56 \\
\hline 7 & Bairatul Luthpiya & 1 & 1 & 2 & 5,8 & 58 \\
\hline 8 & Cicilia Syintia D.N & 1 & 2 & 2 & 5,7 & 57 \\
\hline 9 & Desti Dwi Fitri & 3 & 2 & 3 & 7 & 70 \\
\hline 10 & Dendi Gunawan & 2 & 2 & 3 & 5,5 & 55 \\
\hline 11 & Desi Astri & 1 & 2 & 2 & 7,4 & 74 \\
\hline 12 & Fedry Aji Nugroho & 3 & 2 & 2 & 7 & 70 \\
\hline
\end{tabular}




\begin{tabular}{|c|l|c|c|c|c|c|}
\hline 13 & Hadi Apriadi & 1 & 2 & 2 & 6,5 & 65 \\
\hline 14 & Indamawan & 1 & 1 & 2 & 7 & 70 \\
\hline 15 & Irma Aprilianti & 2 & 3 & 3 & 7 & 70 \\
\hline 16 & Julaiha & 3 & 2 & 2 & 7,4 & 74 \\
\hline 17 & M. Arif Hendrawan & 1 & 2 & 2 & 7 & 70 \\
\hline 18 & Puji Ayu Nadila & 2 & 2 & 3 & 7,4 & 74 \\
\hline 19 & Popy Dwi Purwanti & 2 & 3 & 3 & 5,5 & 55 \\
\hline 20 & Putri Safri Yuni & 2 & 3 & 3 & 6 & 60 \\
\hline 21 & Syahrullah Afdhali & 3 & 2 & 2 & 7,3 & 73 \\
\hline 22 & Ramadhani Saputra & 1 & 2 & 2 & 7 & 70 \\
\hline 23 & Rico Cahyono & 2 & 2 & 3 & 7,4 & 74 \\
\hline 24 & Seggi Hermawan & 2 & 3 & 3 & 5,5 & 55 \\
\hline 25 & Suja'i & 3 & 1 & 2 & 6 & 60 \\
\hline 26 & Suliawati & 1 & 2 & 2 & 7 & 70 \\
\hline 27 & Suci Islamiati & 2 & 2 & 3 & 7,4 & 74 \\
\hline 28 & Tuti Nurdiawati & 2 & 2 & 3 & 5,5 & 55 \\
\hline 29 & Winda Lestari & 2 & 3 & 3 & 6 & 60 \\
\hline 30 & Yati Ariyani & 3 & 2 & 2 & 7 & 70 \\
\hline 31 & Yuliana Nada & 1 & 2 & 2 & 7,4 & 74 \\
\hline 32 & Yuni Lestari & 2 & 2 & 3 & 5,5 & 55 \\
\hline & Jumlah Skor & 35 & 42 & 49 & 209,2 & 2091 \\
\hline & Skor Maksimal & 56 & 58 & 51 & 320 & 3200 \\
\hline & \% Skor Tercapai & 53,85 & 72,41 & 71,83 & 71,83 & 65,34 \\
\hline
\end{tabular}

Tabel 2. Kepercayaan diri Secara Individu pada Tahapan 1

\begin{tabular}{|c|c|}
\hline Kategori & Jumlah Siswa \\
\hline tidak baik & 0 \\
\hline kurang baik & 10 \\
\hline cukup baik & 6 \\
\hline Baik & 16 \\
\hline
\end{tabular}


Berdasarkan Tabel 2 terhadap 22 siswa (71\%) mencapai rerata skor kepercayaan diri siswa pada proses pelayanan layanan bimbingan karir kepercayaan diri siswa lebih dari atau sama dengan 3,50 dengan kategori minimal baik (16 siswa kategori baik dan sebanyak 6 siswa berkategori cukup baik). Dengan demikian perkembangan kepercaan diri siswa siswa secara individu pada Tahapan kesatu dinilai belum berhasil.

\section{HASIL DAN PEMBAHASAN}

\section{Temuan Penelitian Tahap 1}

Berdasarkan data hasil Tahapan terhadap pelaksanakan proses pelayanan layanan bimbingan karir pada Tahapan 1 ini, terhadap temuan-temuan sebagai berikut:

a. Kemampuan kepercaan diri siswa secara individu dalam proses pelayanan layanan bimbingan karir masih lemah $(65,57 \%)$ karena motivasi masih rendah.

b. Hampir semua siswa belum menunjukan perkembagan kepercayaan diri siswa-nya dan masih belum ada yang memperoleh nilai sangat baik (maksimal) terutama pada aspek komunikasi, kerja sama dan percaya diri.

c. Semua kelompok belum menunjukkan perkembanga kepercaan diri siswanya dengan kategori baik dan sangat baik dan kinerja kelompok belum bagus.

d. Aspek empati siswa semuanya belum muncul, semua siswa belum mempunyai rasa kebersamaan, mengahargai orang lain, mengahargai pelajaran, mau berbagi dan menerima masukan dan teman.

Secara individu, baru dari 65,34\% kepercayaan dirir siswa belum berkembang dan belum menunjukan peningkatan yang berarti, baik secara kelompok maupun individu.

Hasil Observasi aktivitas guru dalam proses layanan bimbingan karir pada Tahapan 1 masih tergolong rendah dengan perolehan skor 12,86 atau 58,85\% sedangkan skor idealnya adalah 20 atau 100\%. Hal ini terjadi karena guru lebih 
banyak membacca sendiri dan kurang memberikan kesempatan kepada peserta didik. Berdasarkan hasil Observasi yang telah dilakukan dalam Tahapan 1 kegiatan pelaksanaan tindakan kelas diperoleh data bahwa ketuntasan belajar mengalami kenaikan, sebelum Observasi prosentase ketuntasan belajar adalah hanya 20\%. Pada akhir proses layanan-layanan bimbigan karir pada Tahapan 1 siswa diberi tes formatif 1 dengan tujuan untuk mengetahui tingkat keberhasilan siswa dalam proses layanan-layanan bimbingan karir yang telah dilakukan.

Dari 32 peserta didik, sebanyak 22 siswa dengan dapat memahami dan mengetahui metode layana bimbingan karir kelompok. Pemahaman peserta didik dapat dilihat dari pertanyaan yang diberikan setelah peserta didik selesai prose layanan bimbingan karir, pertanyaan yang diberikan sebanyak 10 pertanyaan, diperoleh hasil sebagai berikut: Dari 32 peserta didik yang dijadikan objek Observasi, sebanyak 8 peserta didik 1Menguasai pemahaman 40\% (jawaban yang benar 4 pertanyaan), 8 peserta didik Menguasia pemahaman 50\% (jawaban yang benar 5 pertanyaan), 6 peserta didik Menguasai pemahaman 60\% (jawaban yang 6 pertanyaan), peserta didik.

Dari data tersebut dapat-dapat diketahui bahwa tingkat pemahaman siswa kelas XII IPA terhadap proses bimbingan masih sangat rendah, dari 32 peserta yang mampu memahami materi hanya 22 peserta didik, (63,63\%), sedangkan 10 peserta didik $(35,37 \%)$ belum memahami.

Pengusaha peserta didik terhadap materi bimbingan pun, masih tergolong kurang dari skor ideal 100 skor perolehan rata-ratanya hanay 65,34\%. Namun telah mengalami kenaikan dari sebelum dilaksanakan Observasi dimana hasil prs test yang rata-ratanya hanay 58.09 mengalami kenaikan menjadi $65,34 \%$ pada post tets Tahapan 1 .

Adapun keberhasilan dan kegagalan yang terjadi pada Tahapan 1 sebagai berikut :

a. Guru belum terbiasa menciptakan suasana bimbingan yang mengarah kepada pendekatan bimbingan menciptakan suasana bimbingan karir kelompok mereka merasa senang dan antusiasi untuk belajar. Hal ini bisa dilihat dari 
hasil Observasi terhdapat minat siswa dalam proses bimbingan hanya mencapai $65,34 \%$.

b. Sebagai siswa belum terbiasa dengan kondisi belajar dengan menggunakan metode layana bimbingan karir kelompok mereka merasa senang dan antuasiasi untuk belajar. Hal ini bisa dilihat dari Observasi terhadap aktivitas siswa dalam proses bimbingan hanya mencapai rata-rata $65,34 \%$

c. Hasil evaluasi Tahapan 1 mencapai $65,34 \%$

d. Masih ada siswa yang belum bisa meneyelesaikan tugas dengan waktu yang ditentukan. Hal ini karena siswa tersebut kurang serius dalam belajar.

e. Masih ada siswa yang kurang memahami materi proses bimbingan untuk memperbaiki kelemahan dan mempertahankan keberhasilan yang telah dicapaikan pada Tahapan pertama, maka pada pelaksanaan Tahapan kedua dapat dibuat perencanaan sebagai berikut:

1) Memberikan motivasi kepada siswa yang mengalami kesulitan

2) Lebih intensif membimbing siswa yang mengalami kesulitan.

3) memberikan pengakuan atau penghargaan (reward).

\section{Tahapan 2}

a. Perencanaan

Perencanaan Tahapan berdasarkan replaning Tahapan pertama, sebagai berikut :

1) Memberikan motivasi kepada siswa agar lebih aktif dalam belajar

2) Lebih intensif membimbing siswa yang mengalami kesulitan

3) Memberikan pengakuan atau penghargaan (reward)

4) Membuat perangakt bimbingan dengan metode layanan bimbingan karir kelompok yang lebih mudah difahami oleh peserta didik.

5) Memfasilitas kegiatan eksperimen

b. Pelaksanaan

penulis masih menerapkan tindakan yang mengacu pada skenario model pelayana layanan bimbingan karir metode layana bimbingan karir kelompok dengan prosedur atau langkah-langkah layanan bimbingan karir yang telah ditentukan dalam pelaksanaan pada Tahapan 1. Dengan keadaan sebagai berikut: 
1) Suasana bimbingan sudah mengarah kepada metode layanan bimbingan karir kelompok. Tugas yang diberikan guru kepada siswa dengan menggunakan lember kerja akademik maupun dikerjakan dengan baik. Setiap siswa menunjukan saling membuat untuk menguasai materi pelajaran yang telah diberikan melalui tanya jawab atau diskusi anatara sesama siswa.

2) Sebagai peserta didik termotivasi untuk bertanya dan menanggapi prestasintasi diri guru.

3) Suasana bimbingan yang efektif dan menyenangkan sudah mulai tercipta.

4) Siswa lebih antusiasi mengikuti proses layanan-layanan bimbingan karir di kelas.

c. Pengamatan (observation)

Adapun hasil Observasi yang telah dilakukan dalam Tahapan 11 kegiatan pelaksanaan tindakan kelas diperoeh data bahwa minat siswa dalam memahami pelajaran mengalami kenaikan. Satelah diadakan Observasi pada Tahapan 1 persentasi keaktifan siswa adalah 68\% setelah diadakan Observasi Tahapan 11 menjadi $87 \%$. Hasil Observasi minat peserta didik dalam proses bimbingan dapat terlihat pada tabel berikut:

Tabel 3. Motivasi Siswa XII IPA

\begin{tabular}{|c|c|c|c|c|c|c|}
\hline \multirow[b]{2}{*}{ No } & \multirow[b]{2}{*}{ Nama perserta didik } & \multirow[b]{2}{*}{ Produk } & \multicolumn{2}{|c|}{ Performasi } & \multirow{2}{*}{$\begin{array}{l}\text { Jumlah } \\
\text { Skor }\end{array}$} & \multirow[b]{2}{*}{ Nilai } \\
\hline & & & Praktik & Sikap & & \\
\hline 1 & A. Gunawan & 2 & 2 & 3 & 7 & 86 \\
\hline 2 & Ade Maulana Lubis & 2 & 3 & 2 & 7 & 88 \\
\hline 3 & Anisa Fernanda & 3 & 3 & 3 & 9 & 86 \\
\hline 4 & Aldi Sanjaya & 3 & 3 & 3 & 9 & 85 \\
\hline 5 & Anisa Fitri & 2 & 2 & 2 & 6 & 86 \\
\hline 6 & Badai & 2 & 2 & 3 & 7 & 80 \\
\hline 7 & Bairatul Luthpiya & 2 & 1 & 2 & 6 & 88 \\
\hline 8 & Cicilia Syintia D.N & 2 & 2 & 2 & 6 & 84 \\
\hline 9 & Desti Dwi Fitri & 3 & 2 & 3 & 7 & 86 \\
\hline 10 & Dendi Gunawan & 2 & 2 & 3 & 7 & 84 \\
\hline
\end{tabular}




\begin{tabular}{|l|l|l|l|l|l|l|}
\hline 11 & Desi Astri & 2 & 2 & 2 & 6 & 70 \\
\hline 12 & Fedry Aji Nugroho & 3 & 3 & 2 & 8 & 86 \\
\hline 13 & Hadi Apriadi & 2 & 2 & 2 & 6 & 86 \\
\hline 14 & Indamawan & 1 & 2 & 2 & 5 & 78 \\
\hline 15 & Irma Aprilianti & 3 & 3 & 3 & 9 & 80 \\
\hline 16 & Julaiha & 3 & 2 & 2 & 7 & 86 \\
\hline 17 & M. Arif Hendrawan & 2 & 2 & 2 & 6 & 78 \\
\hline 18 & Puji Ayu Nadila & 2 & 2 & 3 & 7 & 86 \\
\hline 19 & Popy Dwi Purwanti & 2 & 3 & 3 & 8 & 84 \\
\hline 20 & Putri Safri Yuni & 3 & 3 & 2 & 8 & 86 \\
\hline 21 & Syahrullah Afdhali & 2 & 2 & 2 & 6 & 86 \\
\hline 22 & Ramadhani Saputra & 1 & 2 & 2 & 5 & 78 \\
\hline 23 & Rico Cahyono & 3 & 3 & 3 & 9 & 80 \\
\hline 24 & Seggi Hermawan & 3 & 2 & 2 & 7 & 86 \\
\hline 25 & Sujai & 2 & 2 & 2 & 6 & 78 \\
\hline 26 & Suliawati & 2 & 2 & 2 & 7 & 86 \\
\hline 27 & Suci Islamiati & 2 & 3 & 3 & 8 & 84 \\
\hline 28 & Tuti Nurdiawati & 3 & 3 & 2 & 9 & 80 \\
\hline 29 & Winda Lestari & 3 & 2 & 2 & 7 & 86 \\
\hline 30 & Yati Ariyani & 2 & 2 & 2 & 6 & 78 \\
\hline 31 & Yuliana Nada & 2 & 2 & 3 & 7 & 86 \\
\hline 32 & Yuni Lestari & 2 & 3 & 3 & 8 & 84 \\
\hline & Jumlah Skor & 45 & 47 & 49 & 271 & 2265 \\
\hline & Skor Maksimal & 55 & 53 & 51 & 87,42 & 2711 \\
\hline & \% Skor Tercapai & 81,81 & 88,68 & 96,08 & 71,83 & 83,28 \\
\hline
\end{tabular}

Tabel 4. Motivasi Siswa Secara Individu

\begin{tabular}{|l|l|}
\hline Kategori & Jumlah Siswa \\
\hline tidak baik & 0 \\
\hline kurang baik & 10 \\
\hline
\end{tabular}




\begin{tabular}{|l|l|} 
cukup baik & 6 \\
\hline Baik & 16 \\
\hline sangat baik & 0 \\
\hline & \\
\hline
\end{tabular}

Berdasarkan Tabel terhadap 27 siswa $(85,71 \%)$ mencapai rerata skor kemampuan kepercayaan diri siswa pada proses pelayanan layanan bimbingan karir kepercayaan diri siswa lebih dari atau sama dengan 85,71\% dengan kategori minimal baik ( 5 siswa katagori baik dan 27 berkatagori sangat baik). Dengan demikian perkembangan kepercayaan diri siswa-siswa secara individu pada Tahapan 11 sudah mencapi minimal 85\% siswa berkategori minimal baik, sehingga tindakan pada Tahapan kedua dinilai dianggap sudah berhasil.

\section{Temuan Penelitian Tahap 2}

Berdasarkan data hasil Tahapan terdapat pelaksanaan proses pelayanan layanan bimbingan karir pada Tahapan II ini, terhadap temuan-temuan sebagai berikut :

a. Kemampuan kepercayaan diri siswa secara individu dalam proses pelayanan layanan bimbingan karir sangat baik $(83,28 \%)$ karena motivasi siswa cukup tinggi.

b. Hampir semua siswa telah menunjukan perkembangan kemmapuan kepercaan diri siswa-nya dan sudah ada yang memperoleh nilai sangat baik (maksimal) terutama pada aspek komunikasi, kerja sama dan percaya diri.

c. Semua kelompok telah menunjukan perkembangkan kemampuan kepercayaan diri siswanya dengan kategori baik dan sangat baik dan kinerja kelompok sudah bagus.

d. Aspek empati siswa semuanya telah muncul, semua siswa sudah mempunyai rasa kebersamaan, menghargai orang lain, menghargai pelajaran, mau berbagi dan menerima masukan dari teman.

\section{KESIMPULAN}


Observasi tindakan kelas tentang penggunaan metode layana bimbingan karir kelompok dalam menigkatakan pemahaman siswa pada pelajaran. Telah dilaksanakan dalam 2 Tahapan kegiatan menghasilkan kesimpulan sebagai berikut:

a. Hasil ulangan harian setelah menggunakan bimbingan metode layanan bimbingan karir kelompok mengalami peningkatan yang signifikan yakni $83,28 \%$ sedangkan sebelumnya hanya $65,34 \%$

b. Pelaksanaan Tahapan diperoleh data bahwa kepercayaan diri siswa mengalami kenaikan setelah diadakan Observasi pada Tahapan 1 persentase keaktifan siswa adalah 65,34\% setelah diadakan Observasi pada Tahapan 11 menjadi $83,28 \%$.

c. Setelah diadakan Observasi dengan menggunakan metode layanan bimbingan karir kelompok pada Tahapan 1 persentase keaktifan siswa adalah 65,34\% pada Tahapan 11 menjadi 83,28\%.

d. Bimbingan dengan metode layanan bimbingan karir kelompok memiliki dampak positif dalam meningkatkan kepercayaan diri siswa yang ditandai dengan peningkatan ketuntasan belajar siswa dalam setiap Observasi, yaitu Observasi 1 (65,34\%), Observasi $11(83,28 \%)$.

e. Penerapan metode layanan bimbingan karir kelompok mempunyai pengaruh positif, yaitu dapat meningkatkan kepercayaan diri siswa yang ditujukan dengan hasil wawancara dengan sebagai siswa, rata-rata jawaban siswa menyatakan bahwa siswa tertarik dan berminta dengan metode bimbingan metode layanan bimbingan karir kelompok sehingga mereka termotivasi untuk belajar.

\section{DAFTAR PUSTAKA}

BSNP. 2006, Peraturan Menteri Pendidikan Nasional Republik Indonesia No 22 Tahun 2006 tentang Standar Isi untuk Satuan Pendidikan Dasar dan Menegah. Jakarta: Depdiknas.

Karlina, S. 2013. Bimbingan Kooperatif (Cooperative Learning) sebagai salah satu Strategi Membangun Pengetahuan Siswa. (Online) http://www.sd- 
SOSIAL HORIZON: Jurnal Pendidikan Sosial, Vol. 5, No. 2, Desember 2018

$\underline{\text { bina }}$ telenta.com/arsip artikel/artikel_ina.pdf.diakses tgl 27 Desember 2013.

Kompasiana. 2013. Karakteristik Bimbingan Kooperatif. (Oneline) edukasi.kopasianan.com/...

/karakterisik-bimbingan, diakses tgl 27 Desembar 2013.

Goleman, Daniel. 2004. Emitional Inteligence Kecerdasan Emosional Mengapa EQ Lebih Penting Dari Pada IQ. Jakarta: PT. Gramedia Pustaka Utama.

Ngslim Purwanto. 2002. Psikologi Pendidikan. Bandung: PT. Remaja Rosdakarya.

Tabrani Rusyan. 2001. Pendekatan dalam Proses Layanan-Layanan Bimbingan Karir. Bandung: PT. Remaja Rosdakarya. 